\title{
CrimRxiv
}

\section{Researching Internet Governance: Methods, Frameworks, Futures}

Laura DeNardis, Derrick Cogburn, Nanette S. Levinson, Francesca Musiani

Published on: Sep 01, 2020

DOI: $10.21428 / \mathrm{cb} 6 \mathrm{ab} 371 . f e 26 \mathrm{c} 513$

License: Creative Commons Attribution 4.0 International License (CC-BY 4.0). 
